\title{
Evidence for Involvement of Endogenous Somatostatin in the Galanin-Induced Growth Hormone Secretion in Children
}

\author{
S. LOCHE, N. VISTA, E. GHIGO, S. VANNELli, E. ARVAT, L. BENSO, R. CORDA, S. G. CELLA, \\ E. E. MÜLLER, AND C. PINTOR
}

\begin{abstract}
Department of Pediatrics, Chair of Pediatric Endocrinology, University of Cagliari, Cagliari [S.L., R.C., C.P.]; 3rd Pediatric Clinic [N.V., S.V., L.B.] and Department of Biomedical Endocrinology [E.G., E.A.], Metabolism and Gastroenterology, University of Turin, Turin; and Department of Pharmacology [S.G.C., E.E.M.], University
\end{abstract} of Milan, Milan, Italy

\begin{abstract}
We have evaluated the effects of the combined administration of Galanin (Gal) plus growth hormone-releasing hormone (GHRH) and of pyridostigmine (PD), a cholinergic agonist, plus Gal on GH secretion in 15 children (12 males and three females, age 7.7-14.5 y) with short stature. Children were subdivided into two groups. In group $1(\mathbf{n}=7)$ Gal $(15 \mu \mathrm{g} / \mathrm{kg} \mathrm{h}$ i.v. $)$ plus GHRH (1 $\mu \mathrm{g} / \mathrm{kg}$ i.v. $)$ administration induced a higher GH rise $($ peak $=73.1 \pm 10.2 \mathrm{ng} / \mathrm{mL}$, mean $\pm \mathrm{SD}$; area under the curve $\left.(\mathrm{AUC})=531.9 \pm 78.7 \mathrm{ng} \cdot \mathrm{min} \cdot \mathrm{mL}^{-1}\right)$ than $\mathrm{did}$ GHRH alone (peak $=38.9 \pm 26.5 \mathrm{ng} / \mathrm{mL}, p<0.05 ;$ AUC $\left.=256.9 \pm 165.6 \mathrm{ng} / \mathrm{mL} / \mathrm{min}^{-1}, p<0.005\right)$. Gal had a synergistic effect on the GHRH-induced $G H$ response because the GHRH plus Gal AUC response was significantly higher $(p<0.01)$ than the sum of the areas of response to GHRH and Gal alone. In group $2(n=8)$ PD administration $(60 \mathrm{mg} / \mathrm{kg}$ p.o.) had no significant effects on the Gal-induced GH secretion (peak $=14.9 \pm 8.8$ and $16.0 \pm 9.8 \mathrm{ng} / \mathrm{mL}$ after Gal and $\mathrm{PD}+$ Gal, respectively; AUC $=91.2 \pm 52.1$ and $125.2 \pm 83.6 \mathrm{ng} \cdot \mathrm{mL} \cdot \mathrm{min}^{-1}$ after Gal and PD + Gal, respectively). Our results confirm the ability of Gal to stimulate GH secretion in children, and strengthen the view that its mechanism of action involves modulation of endogenous somatostatin release. (Pediatr Res 27: 405-407, 1990)
\end{abstract}

\section{Abbreviations}

AUC, area under curve

Gal, galanin

GH, growth hormone

GHRH, growth hormone-releasing hormone

SRIF, somatostatin

PD, pyridostigmine

Gal is a 29-amino acid peptide, which was first isolated from porcine intestine (1) and then found in high concentrations in the mammalian CNS $(2,3)$. Gal administration stimulates GH secretion in both animals (4-6) and man (7-9). Studies on its mechanism of action have led to conflicting results. In fact, whereas in animals Gal seems to stimulate GH secretion via hypothalamic GHRH release $(5,6)$, in humans inhibition of endogenous SRIF has been suggested as the mechanism of the

Received July 18, 1989; accepted November 24, 1989.

Correspondence: Dr. Sandro Loche, Cattedra di Endocrinologia Pediatrica, Ospedale Microcitemico, via Jenner, 09100 Cagliari, Italy.
Gal-induced GH secretion. This hypothesis is based on the ability of $\mathrm{Gal}$ to potentiate the $\mathrm{GH}$ response to $\mathrm{GHRH}$ in normal men (8).

The cholinergic system plays a fundamental role in the control of $\mathrm{GH}$ secretion in man (10). Anticholinergic drugs blunt the $\mathrm{GH}$ response to a variety of stimuli, including GHRH. Conversely, administration of cholinergic agonist drugs enhances the $\mathrm{GH}$ response to GHRH in both adults and children (10), and restores $\mathrm{GH}$ secretion after intermittent administration of GHRH (10) as well as in conditions of suppressed GH secretion such as obesity (11) and hyperglycemia (12). Studies in animals have shown that the mechanism by which cholinergic compounds exert their neuroendocrine effects is via inhibition of endogenous SRIF release (13).

Interestingly, Gal has been shown to abolish the inhibitory effect of cholinergic blockade on the GHRH-induced GH secretion in man (14). Moreover, cholinergic antagonists inhibit the $\mathrm{GH}$ release induced by $\mathrm{Gal}(15)$.

In this study we evaluated whether Gal is able to potentiate the GHRH-induced GH release in children, and whether administration of a cholinergic agonist drug, PD, would affect the $\mathrm{GH}$ response to Gal.

\section{MATERIALS AND METHODS}

Fifteen children (12 males and three females) aged 7.7-14.5 y were studied. All children were undergoing clinical and laboratory evaluations for their short stature, and were ultimately found to have constitutional growth delay and/or familial short stature. All had a stature below the 3 rd percentile for age, and a GH response to stimulation $>7.0 \mathrm{ng} / \mathrm{mL}$. All children were prepubertal except for case 8 of Table 2 who was in Tanner 2 stage of sexual maturation. None had taken long-term medication before the study. The studies were carried out under institutionally approved protocols, and informed consent was obtained from the children or from their legal guardians.

Children were randomly assigned to two groups. Children of group $1(n=7)$ were tested on three occasions with 1$) \mathrm{GHRH}$ $1-29$ at the dose of $1 \mu \mathrm{g} / \mathrm{kg}$ i.v.; 2) Gal (synthetic porcine, Inalco, Milan, Italy) infused at the dose of $15 \mu \mathrm{g} / \mathrm{kg} / \mathrm{h}$ for $\mathrm{l} \mathrm{h}$, as previously described (9); 3) Gal plus GHRH; GHRH was administered as above at the start of Gal infusion (time 0). Blood samples were drawn from an indwelling catheter inserted in an antecubital vein at times $-60,-30,0,15,30,60,90$, and 120 $\min$.

All children of group $2(n=8)$ were tested on three occasions with 1 ) PD (Mestinon, Hoffmann La Roche, Italy), $60 \mathrm{mg}$ orally at time -60 ; 2) Gal administered as above; 3) PD plus Gal; PD 
Table 1. GH responses to GHRH, Gal, and GHRH plus Gal in children of group I

\begin{tabular}{|c|c|c|c|c|c|c|c|c|c|}
\hline \multirow[b]{3}{*}{ Case } & \multirow[b]{3}{*}{ Sex } & & & \multicolumn{2}{|c|}{ GHRH } & \multicolumn{2}{|c|}{ GAL } & \multicolumn{2}{|c|}{$\mathrm{GHRH}+\mathrm{GAL}$} \\
\hline & & $\mathrm{CA}^{*}$ & $\mathrm{BA}$ & \multirow{2}{*}{$\frac{\text { Peak }}{(\mathrm{ng} / \mathrm{mL})}$} & \multirow{2}{*}{$\frac{\mathrm{AUC}}{\left(\mathrm{ng} \cdot \mathrm{mL} \cdot \mathrm{min}^{-1}\right)}$} & \multirow{2}{*}{$\frac{\text { Peak }}{(\mathrm{ng} / \mathrm{mL})}$} & \multirow{2}{*}{$\frac{\mathrm{AUC}}{\left(\mathrm{ng} \cdot \mathrm{mL} \cdot \mathrm{min}^{-1}\right)}$} & \multirow{2}{*}{$\frac{\text { Peak }}{(\mathrm{ng} / \mathrm{mL})}$} & \multirow{2}{*}{$\frac{\mathrm{AUC}}{\left(\mathrm{ng} \cdot \mathrm{mL} \cdot \mathrm{min}^{-1}\right)}$} \\
\hline & & & $(\mathrm{y})$ & & & & & & \\
\hline 1 & M & 7.7 & 5.9 & 80.0 & 446.8 & 6.1 & 55.3 & 81.0 & 544.0 \\
\hline 2 & M & 9.5 & 6.1 & 18.1 & 96.9 & 7.3 & 60.8 & 73.0 & 568.8 \\
\hline 3 & M & 9.7 & 8.0 & 46.0 & 335.4 & 14.7 & 71.4 & 65.0 & 481.2 \\
\hline 4 & M & 10.2 & 8.8 & 6.8 & 40.2 & 9.3 & 70.6 & 63.6 & 422.5 \\
\hline 5 & $\mathrm{~F}$ & 11.8 & 9.7 & 14.6 & 118.8 & 4.7 & 40.0 & 76.6 & 522.0 \\
\hline 6 & M & 12.3 & 10.5 & 51.7 & 368.5 & 11.9 & 85.9 & 90.0 & 675.1 \\
\hline \multirow[t]{3}{*}{7} & M & 12.8 & 9.8 & 55.0 & 392.1 & 7.8 & 66.7 & 63.0 & 509.9 \\
\hline & & & Mean \pm SD & 38.9 & 256.9 & 8.8 & 64.4 & $73.1 \dagger$ & $531.9 \ddagger$ \\
\hline & & & & 26.5 & 165.6 & 3.5 & 14.4 & 10.2 & $78.7^{\circ}$ \\
\hline
\end{tabular}

* CA, chronologic age; BA, bone age calculated with the TW2 method.

$\dagger p<0.05$ versus GHRH.

$\ddagger p<0.005$ versus GHRH.

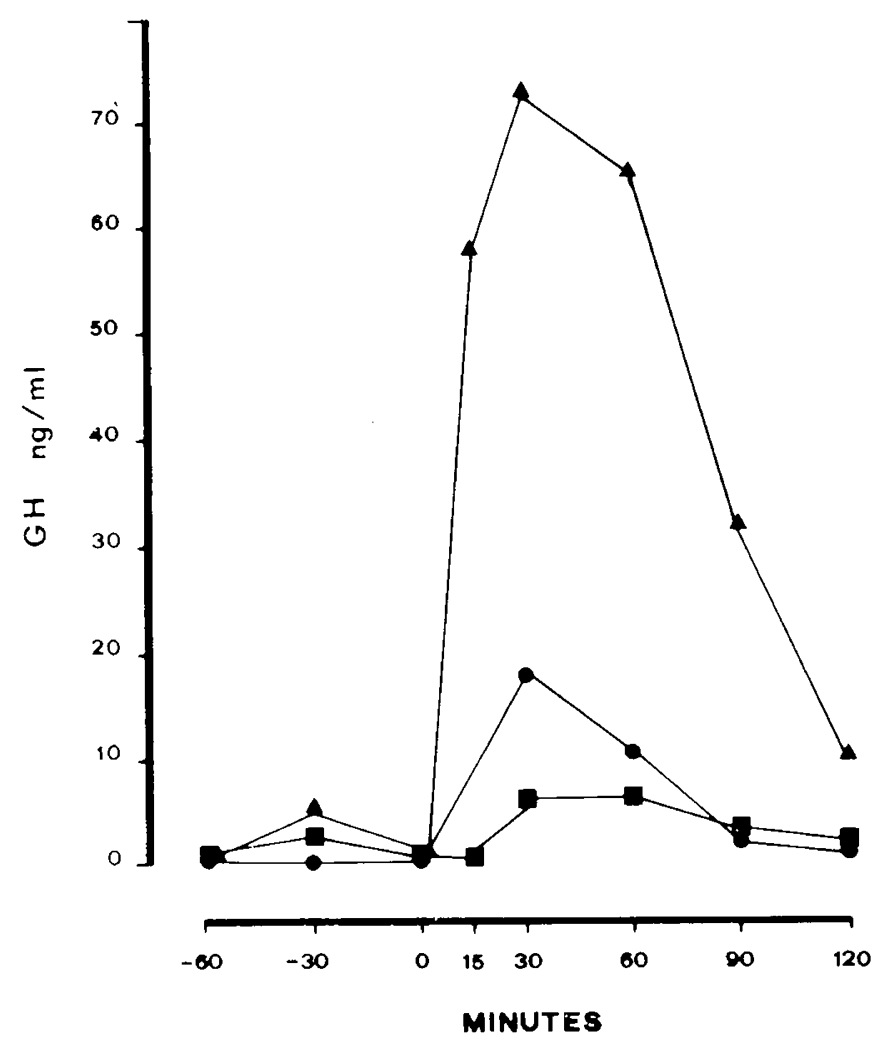

Fig. 1. Plasma growth hormone $(G H)$ levels after GHRH $(\bullet)$, Gal $(\boldsymbol{\square})$, and GHRH plus Gal $(\boldsymbol{\Lambda})$ in a representative child (case 2, Table 1).

was administered orally at time -60 and Gal infusion started at time 0 . Blood samples were drawn as in group 1 .

In both studies the experiments were carried out in random order with an interval of 3-5 d. All experiments started between 0800 and $0900 \mathrm{~h}$ after the children fasted overnight.

GH was measured by double antibody RIA using reagents provided by CEA-IRE Sorin (Italy). The sensitivity of the assay was $0.2 \mathrm{ng} / \mathrm{mL}$ with an intra- and interassay coefficient of variation of 4.5 and $7.9 \%$, respectively.

All values are expressed as peak GH levels or AUC calculated by trapezoidal integration. Statistical analysis of the results was carried out by means of analysis of variance for repeated measures. Paired $t$ test was used to compare GH peak and AUC responses to GHRH and Gal plus GHRH and to Gal and PD plus Gal. All values are given as mean $\pm \mathrm{SD}$.

\section{RESULTS}

Gal administration was well tolerated and apart from a bitter taste in the mouth did not induce noticeable side effects either alone or in combination with PD or GHRH.

Group 1. In all children GHRH administration evoked a prompt clear-cut rise of $\mathrm{GH}$ levels from basal values $(1.4 \pm 1.0$ $\mathrm{ng} / \mathrm{mL}$ ) to peak values of $38.9 \pm 26.5 \mathrm{ng} / \mathrm{mL}(\mathrm{AUC}=256.9 \pm$ $165.6 \mathrm{ng} \cdot \mathrm{mL} \cdot \mathrm{min}^{-1}$ ) (Table 1). After Gal infusion $\mathrm{GH}$ levels rose to $8.8 \pm 3.5 \mathrm{ng} / \mathrm{mL}\left(\mathrm{AUC}=64.4 \pm 14.4 \mathrm{ng} \cdot \mathrm{mL} \cdot \mathrm{min}^{-1}\right)$ (Table 1). Gal significantly enhanced the GH response to GHRH, evaluated either as peak $(73.1 \pm 10.2 \mathrm{ng} / \mathrm{mL}, p<0.05)$ or AUC $\left(531.9 \pm 78.7 \mathrm{ng} \cdot \mathrm{mL} \cdot \mathrm{min}^{-1}, p<0.005\right)($ Table 1$)$.

$\mathrm{Gal}$ had a synergistic effect on the GHRH-induced GH response, since the GHRH plus Gal AUC response was significantly higher $(p<0.01$ by paired $t$ test $)$ than the sum of the areas of response to GHRH and Gal alone. The plasma GH response to GHRH, Gal, and GHRH plus Gal in a representative case is shown in Figure 1.

Group 2. Peak GH levels after $\mathrm{Gal}$ infusion were $14.9 \pm 8.8$ $\mathrm{ng} / \mathrm{mL}\left(\mathrm{AUC}=91.2 \pm 52.1 \mathrm{ng} \cdot \mathrm{mL} \cdot \mathrm{min}^{-1}\right)($ Table 2$)$. Peak GH levels after PD administration were $14.3 \pm 7.0 \mathrm{ng} / \mathrm{mL}$ (AUC $=$ $97.9 \pm 48.3 \mathrm{ng} \cdot \mathrm{mL} \cdot \mathrm{min}^{-1}$ ) (Table 2). Pretreatment with PD caused no significant effects on the Gal-induced GH response evaluated either as peak $(16.0 \pm 9.8 \mathrm{ng} / \mathrm{mL})$ or AUC $(125.2 \pm$ $83.6 \mathrm{ng} \cdot \mathrm{min} \cdot \mathrm{mL}^{-1}$ ) (Table 2). The plasma GH response to PD, $\mathrm{Gal}$, and $\mathrm{PD}+\mathrm{Gal}$ in a representative case is shown in Figure 2 .

\section{DISCUSSION}

Our study confirms the ability of Gal to stimulate GH secretion in children with short stature (9). We have also shown that Gal enhances the GH response to GHRH, confirming previous findings in adults (8). Inasmuch as Gal has been shown to have no direct effects on the pituitary (5), it is conceivable that its effect on GH secretion are mediated by a reduction of endogenous SRIF release. This hypothesis is further supported by the finding of this study that PD had no effects on the Gal-induced GH secretion.

$\mathrm{PD}$ is a cholinergic agonist drug that enhances cholinergic neurotransmission by inhibiting cholinesterases. A large body of evidence indicates that the mechanism by which cholinergic compounds affect $\mathrm{GH}$ secretion in humans is via modulation of hypothalamic SRIF release (10). Had the Gal-induced GH secre- 
Table 2. GH responses to PD, Gal, and PD plus Gal in children of group 2*

\begin{tabular}{|c|c|c|c|c|c|c|c|c|c|}
\hline \multirow[b]{3}{*}{ Case } & \multirow[b]{3}{*}{ Sex } & \multirow[b]{2}{*}{$\mathrm{CA}$} & \multirow[b]{2}{*}{$\mathrm{BA}$} & \multicolumn{2}{|r|}{ PD } & \multicolumn{2}{|c|}{ GAL } & \multicolumn{2}{|c|}{$\mathrm{PD}+\mathrm{GAL}$} \\
\hline & & & & \multirow{2}{*}{$\frac{\text { Peak }}{(\mathrm{ng} / \mathrm{mL})}$} & \multirow{2}{*}{$\frac{\text { AUC }}{\left(\mathrm{ng} \cdot \mathrm{mL} \cdot \mathrm{min}^{-1}\right)}$} & \multirow{2}{*}{$\frac{\text { Peak }}{(\mathrm{ng} / \mathrm{mL})}$} & \multirow{2}{*}{$\frac{\mathrm{AUC}}{\left(\mathrm{ng} \cdot \mathrm{mL} \cdot \mathrm{min}^{-1}\right)}$} & \multirow{2}{*}{$\frac{\text { Peak }}{(\mathrm{ng} / \mathrm{mL})}$} & \multirow{2}{*}{$\frac{\text { AUC }}{\left(\mathrm{ng} \cdot \mathrm{mL} \cdot \mathrm{min}^{-1}\right)}$} \\
\hline & & & (y) & & & & & & \\
\hline 1 & $\mathrm{M}$ & 9.4 & 7.9 & 22.8 & 142.4 & 12.2 & 64.3 & 17.5 & 128.1 \\
\hline 2 & $\mathrm{M}$ & 9.6 & 9.1 & 16.7 & 112.1 & 18.0 & 98.7 & 17.5 & 113.0 \\
\hline 3 & $\mathrm{~F}$ & 10.1 & 10.0 & 11.0 & 70.8 & 20.4 & 85.6 & 15.4 & 115.5 \\
\hline 4 & M & 10.4 & 8.9 & 19.0 & 180.1 & 13.2 & 70.9 & 17.7 & 136.6 \\
\hline 5 & $\mathrm{M}$ & 10.7 & 9.5 & 12.8 & 78.7 & 6.1 & 153.1 & 13.6 & 108.4 \\
\hline 6 & $\mathrm{M}$ & 12.1 & 11.0 & 22.0 & 113.2 & 32.7 & 181.3 & 36.4 & 312.1 \\
\hline 7 & $\mathrm{M}$ & 14.0 & 13.5 & 5.5 & 48.4 & 9.8 & 45.8 & 6.3 & 52.9 \\
\hline \multirow[t]{3}{*}{8} & $\mathrm{~F}$ & 14.5 & 14.0 & 4.6 & 37.6 & 6.7 & 29.6 & 3.9 & 35.2 \\
\hline & & & Mean \pm SD & 14.3 & 97.9 & 14.9 & 91.2 & 16.0 & 125.2 \\
\hline & & & & 7.0 & 48.3 & 8.8 & 52.1 & 9.8 & 83.6 \\
\hline
\end{tabular}

* Abbreviations as in Table 1.

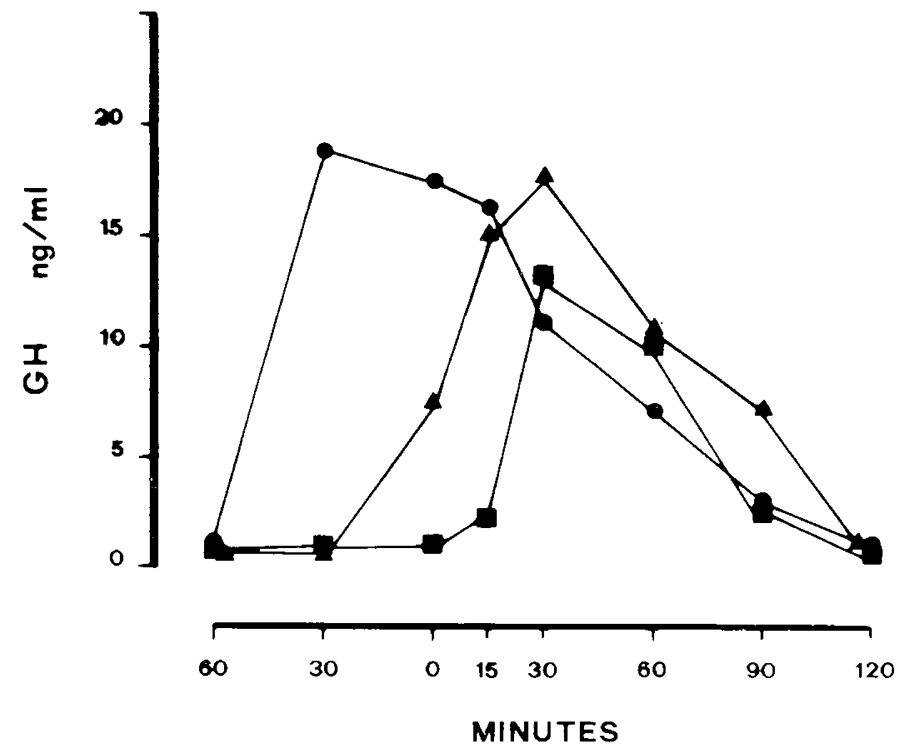

Fig. 2. Plasma growth hormone $(G H)$ levels after pyridostigmine $(\mathbf{O})$, Gal ( $\mathbf{\square})$, and PD plus $G a l(\mathbf{\Delta})$ in a representative child (case 3 , Table 2 ).

tion been due to stimulation of endogenous GHRH release, one would have expected a higher response to Gal plus PD versus Gal alone, a fact that did not occur in this study. In this context it is noteworthy that PD not only enhances the $\mathrm{GH}$ response to GHRH, but also to clonidine (16), which reportedly stimulates GH secretion via GHRH (10).

Our results thus indicate that $\mathrm{Gal}$ and PD probably stimulate GH release via a final common pathway, i.e. by inhibition of SRIF release. Alternatively, Gal may act to facilitate cholinergic neurotransmission. In this regard, there is extensive overlap of Gal-like immunoreactivity and acetyltransferase-like immunoreactivity in large areas of the rat CNS (17), although Gal is able to inhibit acetylcholine release in the ventral hippocampus in the rat (18).

In conclusion, our data, although confirming the ability of Gal to stimulate GH secretion in children (9), strengthen the view that its mechanism of action involves modulation of endogenous SRIF release.

\section{REFERENCES}

1. Tatemoto K, Rökaeus Å, Jöruvall H, McDonald TJ, Mutt V 1983 Galanina novel biologically active peptide from porcine intestine. FEBS Lett
$164: 124-128$

2. Rökaeus $\AA$, Melander $T$, Hökfelt $T$, Lundberg $J M$, Tatemoto $K$, Carlquist $M$, Mutt V 1984 A galanin-like peptide in the central nervous system and intestine of the rat. Neurosci Lett 47:161-166

3. Skofitsch G, Jacobowitz DM 1985 Immunohistochemical mapping of galaninlike neuron in the rat central nervous system. Peptides 6:509-546

4. Murakami Y, Kato Y, Koshiyama H, Inoue T, Yanaihara N, Imura H 1987 Galanin stimulates growth hormone $(\mathrm{GH})$ secretion via $\mathrm{GH}$-releasing factor (GRF) in conscious rats. Eur J Pharmacol 136:415-418

5. Ottlecz, A, Samson WK, McCann SM 1986 Galanin: evidence for a hypothalamic site of action to release growth hormone. Peptides 7:51-53

6. Cella SG, Locatelli V, De Gennaro V, Bondiolotti GP, Pintor C, Loche S. Provezza M, Müller EE 1988 Epinephrine mediates the growth hormonereleasing effect of galanin in infant rats. Endocrinology 122:855-859

7. Bauer FE, Ginsberg L, Venetikou M, MacKay DJ, Burrin JM, Bloom SR 1986 Growth hormone release in man induced by galanin, a new hypothalamic peptide. Lancet 2:192-194

8. Davis TME, Burrin JM, Bloom SR 1987 Growth hormone (GH) release in response to GH-releasing hormone in man is 3-fold enhanced by galanin. J Clin Endocrinol Metab 65:1248-1252

9. Loche S, Cella SG, Puggioni R, Stabilini L, Pintor C, Müller EE (1989) The effects of galanin on growth hormone secretion in children of normal and short stature. Pediatr Res 26:316-320

10. Müller EE, Locatelli V, Ghigo E, Loche S, De Gennaro Colonna V, Cocchi D, Pintor C, Camanni F 1989 Involvement of brain neurotransmitters in the control of growth hormone secretion. In: Frish $\mathrm{H}$, Thorner MO (eds) Hormonal Regulation of Growth, Vol 58. Serono Symposia. Raven Press, New York, pp 49-62

11. Loche S, Pintor C, Cappa M, Ghigo E, Puggioni R, Locatelli V, Müller EE 1989 Pyridostigmine counteracts the blunted growth hormone response to growth hormone releasing hormone of obese children. Acta Endocrinol 120:624-628

12. Balzano S, Loche S, Murtas ML, Fanni T, Sica V, Pintor C, Martino E 1989 Potentiation of cholinergic tone counteracts the suppressive effect of oral glucose administration on the GH response to GHRH in man. Horm Metab Res 21:52-53

13. Locatelli V, Torsello A, Redaelli M, Ghigo E, Massara F, Müller EE 1986 Cholinergic agonist and antagonist drugs modulate the growth hormone response to growth hormone-releasing hormone in the rat. Evidence for mediation by somatostatin. J Endocrinol 111:271-278

14. Chatterjee VKK, Ball JA, Proby C, Burrin JM, Bloom SR 1987 Galanin abolishes the inhibitory effect of cholinergic blockade on growth hormonereleasing hormone-induced secretion of growth hormone in man. J Endocrinol 116:R1-R2

15. Chatterjee VKK, Ball JA, Davis TME, Proby C, Burrin JM, Bloom SR 1988 The effect of cholinergic blockade on the growth hormone response to galanin in humans. Metabolism 37:1089-1091

16. Ghigo E, Goffi S, Mazza E, Imperiale E, Arvat E, Bellone J, Procopio M, Müller EE, Camanni F 1989 Acute administration of pyridostigmine and clonidine has an additive stimulatory effect on $\mathrm{GH}$ release in normal children. J Endocrinol Invest 12:99-101

17. Melander T, Staines WA, Rökaeus $\AA 1986$ Galanin-like immunoreactivity in hippocampal afferents in the rat, with special reference to cholinergic and noradrenergic inputs. Neuroscience 19:223-240

18. Fisone G, Wu CF, Consolo S, Nordström Ö, Brynne N, Bartfai T, Melander T, Hökfelt T 1987 Galanin inhibits acetylcholine release in the ventral hippocampus of the rat: histochemical, autoradiographic in vivo and in vitro studies. Proc Natl Acad Sci USA 84:7339-7343 